\title{
Rootcrops processing waste management by Pyrolysis conversion
}

\author{
Ramon R. Orias ${ }^{1 *}$
}

\begin{abstract}
Submitted: 12 October 2019 | Accepted: 09 June 2020

The waste products derived from the commercial processing of root crops are the soiled peels, trimmings, root tissues, and by-products like pulp fibers obtained from the finishing operations. These bulky waste products create the management problems of safe storage and environmentally sound disposal.

Processing the wastes from cassava was found to be the most suitable for pyrolysis conversion from among the rootcrops considered. Results showed that, of the four (4) cassava waste forms, larger briquette was found to have the highest vinegar yield conversion at $1.842 \mathrm{~L} \mathrm{~kg}^{-1}$ while the shred form had the lowest at $1.203 \mathrm{~L}$ $\mathrm{kg}^{-1}$. The rate of vinegar production was also fastest from the briquettes at $2.388 \mathrm{~L} \mathrm{~h}^{-1}$ and lowest from the raw form at $1.544 \mathrm{~L} \mathrm{~h}^{-1}$. Better vinegar yields were therefore associated with solid fuel forms, smaller bed porosity, smaller surface reaction area, and lower gasification temperature. Other factors that also affected vinegar production were the loading rates, air supply conditions, and heat exchanger efficiency. In this study, the available Logarithmic Mean Temperature Difference (LMTD) was only $45.67^{\circ} \mathrm{C}$, indicative of poor performance of the exchanger unit. The heat exchanger unit's design can be improved in future experiments by using good thermal conducting materials, reconfiguration, and increasing the conductor interface area. This should result in higher vinegar yields.
\end{abstract}

Keywords: Rootcrops, processing wastes, pyrolysis conversion, wood vinegar, flue gas temperature

\section{INTRODUCTION}

\section{Processing Waste}

Crop-based processing plants produce incidental products considered as wastes of lesser economic value and environmentally hazardous. When these

${ }^{1}$ Root Crop Research and Training Center, Visayas State University, Baybay City, Leyte 6521 Philippines

*Corresponding Author. Address: Root Crop Research and Training Center, Visayas State University, Baybay City, Leyte6521 Philippines; Email: rorias95@yahoo.com

DOI: $10.32945 /$ atr42211.2020 
processing plants are run on a commercial scale, these wastes could cause an alarming problem for handling and disposal requiring additional management costs. Various waste management measures are available, such as conversion into fertilizer, animal feed and biomass fuel, but conversion by pyrolysis into a beneficial product still needs more exploration. For the rootcrops industry, particularly cassava and sweetpotato, the primary products with commercial value are dried powders called flour and starch, but with promising prospects as a possible major source of low-gluten flour. The waste products derived from the primary processing operations are the soiled peels, trimmings, root tissues, and by-products like pulp fibers obtained from the finishing operation. Usually, these are unutilized and disposed of in open dumpsites to degrade for a few years until they become garden soil. Cassava wastes (20-23\%) are significantly larger than sweetpotato wastes (8$10 \%$ ) based on fresh tuber weight, as shown in Figures $1 \& 2$. The lower amount of processing waste from sweetpotato is attributed to the improved minimal peeling method adopted in the process.

This study was conducted at the Philippine Root Crop Research and Training Center (PhilRootcrops) at the Visayas State University main campus, Visca, Baybay City, Leyte, Philippines, to enhance waste utilization from rootcrop processing through conversion into a pyroligneous acid called wood vinegar and thereby deriving more economic value from the product. Approximately 12tons waste per 50tons input capacity plant.

These processing wastes, which are mostly root barks or peels, chunks of rejected root parts, basal ends and tips, root tissues, and field dirt, are discharged as aggregates during the initial cleaning and inspection operation together with wash water. Other post-processing by-products are the pith fibers and coarse particles with a lower volume (3\%), which are obtained during the fine powder finishing operation.

\section{Wood Vinegar Production}

Wood vinegar is a sub-product of charcoal production from biomass substrate. It is the liquid condensate simultaneously produced by the cooling of the gas generated from the partial combustion of cellulose materials burnt under an oxygen deficient-atmosphere. The beneficial uses of wood vinegar in agriculture include soil quality improvements, pest control, and accelerator in plant growth. However, it becomes slightly toxic to plants and animals if applied at high concentrations (FFTC 2017). Approximately 300 components are found in wood vinegar, such as acetic acid, methanol, phenol, esters, acetals, ketones, formic acid, and many others. All of these compounds work synergistically as co-enzymes and catalysts. Henceforth, the usage of wood vinegar under-regulated concentration is safe to plants and animals because it is organic rather than using those manufactured chemical pesticides and chemical insecticides, which are both costly and detrimental to the environment. Past researches on the use of wood vinegar were first carried out using biomass substrates like timbers, coco-shells, husks, rice hulls. Vinegar production from these agricultural wastes has been proven effective and technically feasible with the availability of efficient equipment to facilitate the extraction process. Countries that produce wood vinegar now are Japan, China, Indonesia, Malaysia, Brazil, and South American countries. It has been widely reported to be effective against rosette or green mosaic in wheat, nematode in sweetpotato, tobacco mosaic, and powdery mildew in leafy vegetables, leaf miner 


\section{Rootcrops processing waste management}

and other insect pests (Leong 2011). For cassava, which is considered the most soil-nutrient depleting rootcrop, transforming its processing wastes into wood vinegar would be a good payback farming practice and favorable input when applied back to the ground to enhance soil fertility and quality.

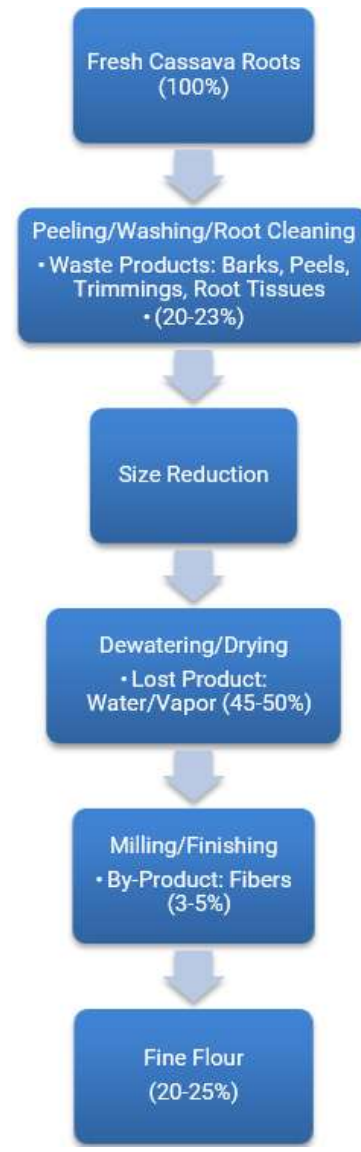

Figure 1. Process flow and material balance in cassava flour processing
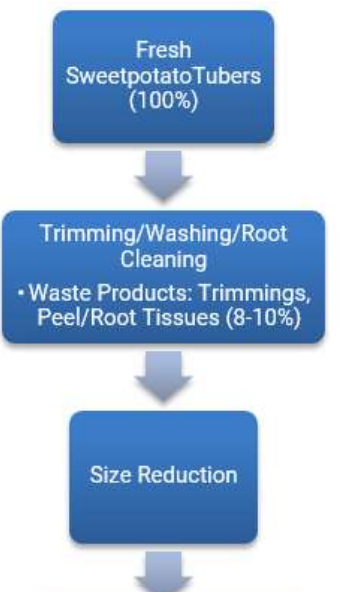

Dewatering/Drying

- Lost Product:

Water/Vapor (64-66\%)

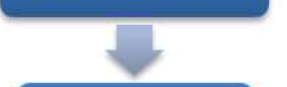

Milling/Finishing

- By-Product: Fibers
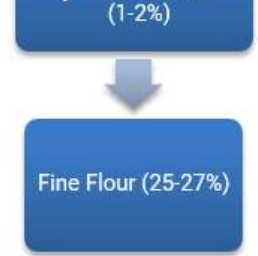

Figure 2. Process flow and material balance in sweetpotato flour processing

Based on initial experiments, processing wastes from cassava was more productive than sweetpotato, which produces only a minimal amount of vinegar. Therefore this study focused on cassava as a substrate.

\section{Objectives of the Study}

Primarily the study intended to establish a system for the beneficial utilization of processing wastes from rootcrops through pyrolytic vinegar conversion. Specific objectives were as follows: 1 ) to determine vinegar yield $\left(\mathrm{L} \mathrm{kg}^{-1}\right)$ using various forms of rootcrop processed waste, 2) to evaluate vinegar production rate $\left(L h^{-1}\right)$ as affected by the feed rate, combustion temperature and fuel form, and 3 ) to establish relevant variable conditions for optimum vinegar production operation. 


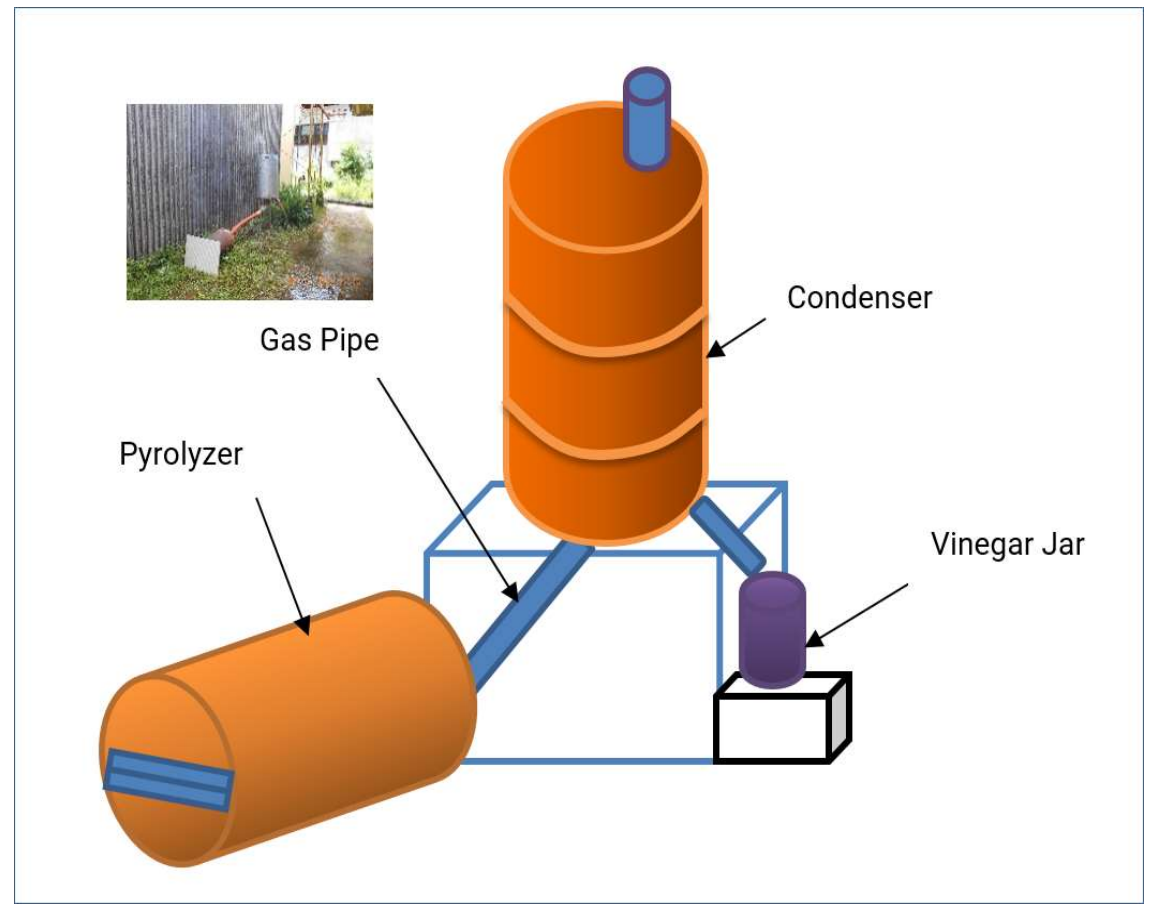

Figure 3. Schematic set-up for the wood vinegar generator with the inset actual picture

\section{MATERIALS AND METHODS}

A prototype wood vinegar generator earlier developed by PhilRootcrops (Figure 3) was used to extract the vinegar using different forms of prepared feed materials. It has three main parts: the pyrolyzer, stack gas conduit, and condenser. The performance of the generator was evaluated based on the following factors: liquid vinegar yield per kg; rate of production; pyrolysis characteristics as affected by the feed rate, feed form or configuration, as well as the condenser temperature gradient. The condensation process was facilitated through a heat exchangerconcentric drums assay that separates the gas from the running water jacket.

\section{Feed Fuel Preparation}

Fresh wastes from an existing cassava flour production system at PhilRootcrops were gathered in a large amount enough to cover the whole experimental operations. These processing wastes were comprised of mostly peels, infested root tissues, trimmed ends, and some trash dirt collected during the washing and cleaning operation. Old decaying wastes were excluded in this study. In preparation to become feed fuel for the pyrolyzer, the raw wastes were first dried under the sun for a week or until thoroughly dried in equilibrium with the atmosphere. Finer particles and dust sands were eventually dissociated and dropped to the ground from the whole stock during the drying process. Four forms of feed fuel were prepared as treatment variables. These are shown in Figure 4 and are described below: 


\section{Rootcrops processing waste management}

a) Raw Feed (PWC1) - these are the original heterogeneous mixture of processing wastes which were thoroughly dried to $10-12 \% \mathrm{Mc}_{\mathrm{wb}}$. It appeared loose and unsegregated with various sizes and shapes.

b) Shred Feed (PWC2) - the raw dried wastes were cut into small particles by shearing so that it appears as coarse particles but with more homogeneous sizes and shape.

c) Small Briquette Feed (PWC3) - the coarse dry wastes were molded into small briquettes using wet cassava starch as a binder. The cassava starch to water to waste ratio is $80 \mathrm{~g}: 1 \mathrm{~L}: 1 \mathrm{~kg}$, respectively. The molder was made of a cylindrical die with dimensions of $2 \mathrm{~cm}$ diameter $\times 5 \mathrm{~cm}$ length. Compacting was done manually with a wood-bat. The molded briquettes were dried to solidify.

d) Large Briquette Feed (PWC4) - same as PWC3 but with larger dimensions of $3.5 \mathrm{~cm}$ diameter $\times 7.5 \mathrm{~cm}$ length.

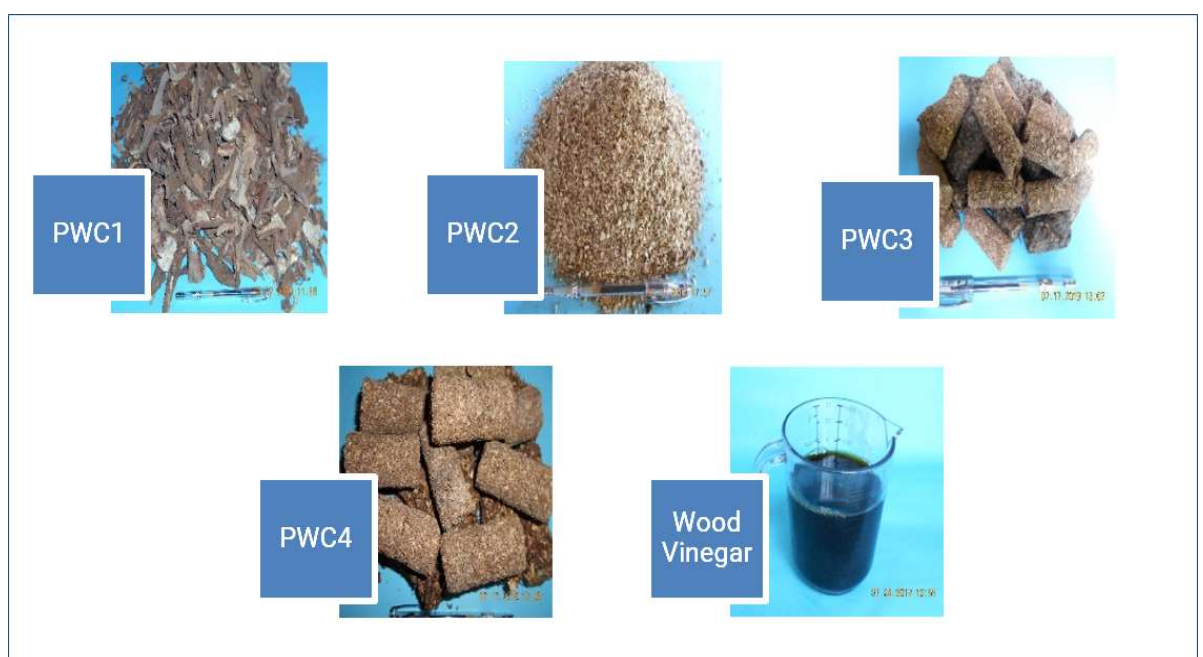

Figure 4. Processing wastes raw, as prepared into different fuel feed forms and the output product wood vinegar

Moisture contents of these prepared feed fuels were determined by oven method, using the following formula:

Where:

$$
\boldsymbol{M}_{w b}=\frac{W_{i}-W_{d b}}{W_{i}} \times 100
$$

$$
\begin{aligned}
& M_{w b}=\text { moisture content, wet basis }(\%) \\
& W_{i}=\text { initial weight of the sample }(g) \\
& W_{d b}=\text { final or bone-dry weight of the sample }(g)
\end{aligned}
$$

Physical characteristics were measured in terms of particle and briquette dimensions, particle density, and bulk density in terms of mass per unit volume by 
the water displacement method. The surface area projection of each particle and briquette was theoretically based on a cylindrical shape. Porosity was calculated as the void fraction property within the bed condition. Also, the effective reaction area of each fuel type was measured in terms of the total projected surface area per unit mass. The following formula was used:

$$
\varepsilon=1-\frac{P b}{P p}
$$

Where:

$$
\begin{aligned}
& \varepsilon=\text { porosity, } \% \\
& \rho_{\mathrm{b}}=\text { bulk density, } \mathrm{kg} / \mathrm{m}^{3} \\
& \boldsymbol{\rho}_{\mathrm{p}}=\text { particle density, } \mathbf{~ k g} / \mathrm{m}^{3}
\end{aligned}
$$

$$
A_{2}=\frac{A_{1}}{P_{p} V_{p}}
$$

Where:

$$
\begin{aligned}
& A_{2}=\text { specific surface area of reaction, } \mathrm{m}^{2} \mathrm{~kg}^{-1} \\
& A_{1}=\text { particle surface area, } \mathrm{m}^{2} \\
& P_{p}=\text { particle density, } \mathrm{kg} / \mathrm{m}^{3} \\
& V_{p}=\text { particle volume, } \mathrm{m}^{3}
\end{aligned}
$$

\section{Loading Rate Control}

Three loading rates were regulated based on the minimum amount of load the burner can hold in a single layer and the maximum volume that it can fully accommodate. The minimum load condition was characterized as just enough amount of fill the bin without creating empty spaces on the floor bed. The maximum load was determined with the full piling of the material but just enough not to spill over the bin. The controlled loading rates maintained were as follows: $L_{1}=1.00 \mathrm{~kg} \mathrm{~h}^{-1}$; $\mathrm{L}_{2}=1.25 \mathrm{~kg} \mathrm{~h}^{-1}$; and $\mathrm{L}_{3}=1.50 \mathrm{~kg} \mathrm{~h}^{-1}$. Loads were intermittently supplied.

\section{Vinegar Generator Set-up}

The prototype wood vinegar generator earlier developed at PhilRootcrops and as evaluated by Tardo in $\mathbf{2 0 1 6}$ was originally designed for agricultural wastes like wood, coconut husks, and shells. This was modified to suit the different type of feed fuel in this experiment. The major modification done was mainly to the pyrolyzer component, as shown in Figure 3. The original door opening at one end of the pyrolizer drum was replaced with a drawer box that serves as a holding bin for the feed fuel material. The stack gas pipe was reconstructed with a larger diameter of 3 in. pipe of the same material. Lastly, the condenser component was mounted slightly higher than the original elevation. The set-up was assembled outdoors on level ground but near a continuously running water tap. The feed fuels were readied near the door of the pyrolyzer, the stack gas pipe was attached at the other end and then coupled to the condenser unit through the smoke inlet pipe. 


\section{Rootcrops processing waste management}

\section{Experimental Operation}

The following procedure was generally followed for each experimental run, with every run representing a replication and certain treatment combination:

a) To start, water drawn by a flexible hose from the source tap was allowed to fill the condenser tank until it flowed continuously. It was kept flowing for three minutes or until the temperature in the drum stabilized before charging the pyrolyzer.

b) A certain amount of feed fuel was loaded in the drawer box, ignited with enough fire sparing some amount of fuel to burn while outside the pyrolyzer.

c) The box burner was loaded into the pyrolyzer chamber and the closure of the shutter regulated. The chamber was kept in smoking condition. As much as possible, rapid-fire build-up was avoided by closing the shutter and leave a small opening to admit a limited amount of air. It was opened wider when the carbonization process slowed down.

d) The start time of ignition ( $\mathrm{min}$ ), time of closing the chamber, and start-time of wood vinegar to appear at the discharge tube was recorded.

e) The various temperatures $\left({ }^{\circ} \mathrm{C}\right)$ at the pyrolyzing chamber, water inflow, water outflow, and vent pipe of the condenser unit was recorded.

f) The end time ( $\mathrm{min}$ ) of vinegar appearance was recorded.

g) The amount of vinegar collected ( $L$ ) was recorded as well as the total amount of fuel used $(\mathrm{kg})$ during a period of $3 \mathrm{~h}$ for each experimental run.

h) It was ensured that the feed fuel in the chamber was fully transformed into chars by the end of each $3 \mathrm{~h}$ run.

\section{Data Calculated}

The following data were calculated based on the data recorded on volume, weights, time, and temperature for each treatment variable:

a) Feed fuel physical characteristics - the initial moisture content of the prepared fuels fed to the pyrolyzer was determined using the oven method using Equation 1, porosity value using Equation 2, and reaction area using Equation 3.

b) Vinegar yield - the total amount of vinegar $\left(\mathrm{L} \mathrm{kg}^{-1}\right)$ extracted per $\mathrm{kg}$ of feed fuel material as evaluated at different feeding rates.

c) Production rate - the amount of vinegar extracted per unit time $\left(\mathrm{Lh}^{-1}\right)$ as affected by different feed rates, outcome temperatures, and fuel forms.

d) Water temperature - the water temperatures $\left({ }^{\circ} \mathrm{C}\right)$ entering and leaving the condenser unit were recorded.

e) Gas temperature - the temperatures $\left({ }^{\circ} \mathrm{C}\right)$ of flue gas entering and exiting the condenser unit were recorded.

f) Logarithmic Mean Temperature Difference (LMTD) - the mean temperature gradient as the facilitating factor in the exchange of heat between the flue gas and water $\left({ }^{\circ} \mathrm{C}\right)$, can be calculated in the ff: 


$$
L M T D=\frac{\Delta T_{A}-\Delta T_{B}}{\ln \frac{\Delta T_{A}}{\Delta T_{B}}}
$$

Where:

$$
\begin{aligned}
& \Delta \mathrm{T}_{\mathrm{A}}=\text { temperature difference between inflows at one junction }\left({ }^{\circ} \mathrm{C}\right) \\
& \Delta \mathrm{T}_{\mathrm{B}}=\text { temperature difference between outflows at other junction }\left({ }^{\circ} \mathrm{C}\right)
\end{aligned}
$$

\section{Statistical Analysis}

Analysis of variance was based on 2-Factor Factorial Design with twelve (3x4) treatment combinations among feed form and loading rate. The four feed forms namely: the Raw (PWC1), Shred (PWC2), and Small Briquette (PWC3), and Large Briquette (PWC4) were fed at three different rates, namely: $1.00 \mathrm{~kg} \mathrm{~h}^{-1}\left(\mathrm{~L}_{1}\right) ; 1.25 \mathrm{~kg} \mathrm{~h}^{-1}$ $\left(\mathrm{L}_{2}\right)$; and $1.50 \mathrm{~kg} \mathrm{~h}^{-1}\left(\mathrm{~L}_{3}\right)$. Each treatment combination was replicated three (3) times, so a total of 36 experimental runs were conducted. Differences between treatment means were compared using Tukey HSD test.

\section{RESULTS AND DISCUSSION}

\section{Feed Fuel and Bed Characteristics}

Initial moisture content (MC) of cassava processing waste was generally at $68-70 \%$, wet basis. It had achieved $8-12 \%$ equilibrium MC after being solar dried for 7 days, with larger materials having a higher equilibrium moisture level. Other physical characteristics data are shown in Table 1. Raw feed fuel (PWC1) was so heterogeneous in size and shape ranging from $4 \mathrm{~mm}$ fine particles $(5 \%)$ to $1.96 \mathrm{~cm} \times 6.75 \mathrm{~cm} \times 15.60 \mathrm{~cm}$ mean dimensions in thickness, widths, and lengths for large chunks of waste (95\%). Other properties, such as particle and bulk densities, are likewise tabulated. The porosity value, which indicates void fraction in the bed, was observed in the largest raw feed at $81.25 \%$ and smallest in large briquettes at $44.44 \%$. In terms of total reaction area $\left(\mathrm{A}_{2}\right)$, it was highest when the fuel was transformed into coarse particles at $1.71 \mathrm{~m}^{2} \mathrm{~kg}^{-1}$ mass and again smallest in large briquettes at $0.26 \mathrm{~m}^{2} \mathrm{~kg}^{-1}$ mass of fuel. Reaction area is an important factor that theoretically affects the combustion and gasification processes, and consequently, in the production of condensable gases.

\section{Vinegar Yield}

Production of wood vinegar was significantly affected by the different forms of fuel and the loading rate. As shown in Table 2 and Figure 5, briquette forms generally have higher yields than the raw forms, with the highest value obtained from the larger briquettes at $1.892 \mathrm{~L} \mathrm{~kg}^{-1}$ and the lowest yield from the raw fuel at $1.203 \mathrm{~L} \mathrm{~kg}^{-1}$. This shows that molding the fuel into briquettes is indeed advantageous over the loose fuel. Higher yields were also observed at higher loading rates of $1.5 \mathrm{~kg} \mathrm{~h}^{-1}$. This indicated that feeding the pyrolyzer at a lower rate of loosely filled fuel would result in more combustion rather than on gasification into the production of condensable gases. Therefore, feeding with the fuel has to be at the maximum rate that the chamber can accommodate. 


\section{Rootcrops processing waste management}

Table 1. Physical characteristics of the different feed fuels

\begin{tabular}{cccccccc}
\hline Feed Fuel & Diameter, $\mathrm{D}$ & Length, $\mathrm{L}$ & $\begin{array}{c}\text { Particle } \\
\text { Density, } \rho_{\mathrm{p}}\end{array}$ & $\begin{array}{c}\text { Bulk } \\
\text { Density, } \rho_{\mathrm{b}}\end{array}$ & $\begin{array}{c}\text { Porosity, } \\
\varepsilon\end{array}$ & $\begin{array}{c}\text { Surface } \\
\text { Area, } \mathrm{A}_{1}\end{array}$ & $\begin{array}{c}\text { Reaction } \\
\text { Area, } \mathrm{A}_{2}\end{array}$ \\
\hline & $\mathrm{cm}$ & $\mathrm{cm}$ & $\mathrm{Kg} \mathrm{per \textrm {m } ^ { 3 }}$ & $\mathrm{Kg} \mathrm{per \textrm {m } ^ { 3 }}$ & $\%$ & $\mathrm{~cm}^{2}$ per pc & $\mathrm{m}^{2}$ per kg \\
PWC1 & $0.4-2.0$ & $2.0-15.6$ & 882.24 & 296.67 & 81.25 & 53.38 & 0.61 \\
PWC2 & $0.4-0.6$ & 0.6 & 386.36 & 113.32 & 70.67 & 0.78 & 1.71 \\
PWC3 & 2.0 & 5.0 & 565.50 & 372.53 & 34.12 & 37.70 & 0.42 \\
PWC4 & 3.5 & 7.5 & 563.20 & 312.89 & 44.44 & 101.71 & 0.26 \\
\hline
\end{tabular}

At this juncture, we can conclude that the production of condensable gases during the carbonization process would be maximized under the minimal surface area of reactions and smaller bed porosity as found in briquette materials (Table 1). In the combustion process, the larger surface area projected by the fuel and sufficient air access in larger pore spaces results in favorable conditions that would allow more efficient combustion to occur in the chamber. As a result, there will be more flames and carbon dioxide produced and less of the condensable gases generated. For the production of wood vinegar, these conditions of a lesser reaction area of the fuel and a limited supply of air have to be regulated and maintained for optimum yield.

Table 2. Means of vinegar outputs $\left(\mathrm{L} \mathrm{kg}^{-1}\right)$ extracted from different processing waste form from cassava and at different loading rates

\begin{tabular}{ccccc}
\hline \multirow{2}{*}{ Feed Fuel } & \multicolumn{3}{c}{ Loading Rate $\left(\mathrm{kg} \mathrm{h}^{-1}\right)$} & \multirow{2}{*}{$\begin{array}{c}\text { Mean }^{* *} \\
\left(\mathrm{~L} \mathrm{~kg}^{-1}\right)\end{array}$} \\
\cline { 2 - 4 } & $\mathrm{L}_{1}$ & $\mathrm{~L}_{2}$ & $\mathrm{~L}_{3}$ & $1.203^{\mathrm{a}}$ \\
PWC1 & 0.981 & 1.166 & 1.463 & $1.339^{\mathrm{a}}$ \\
PWC2 & 1.085 & 1.363 & 1.570 & $1.792^{\mathrm{b}}$ \\
PWC3 & 1.343 & 1.692 & 2.340 & $1.842^{\mathrm{b}}$ \\
PWC4 & 1.381 & 1.740 & 2.405 & 1.544 \\
\hline Mean & $1.197^{\text {a }}$ & $1.490^{\mathrm{a}}$ & $1.944^{\mathrm{b}}$ & \\
\hline
\end{tabular}

Treatment means having same letter are not significantly different at $1 \%$ level of significance Legend:

PWC1 = raw form, $P W C 2=$ shred form, $P W C 3=$ small briquette, $P W C 4=\operatorname{large~briquette~forms~} L_{1}=1.00 \mathrm{~kg} \mathrm{~h}^{-1}, L_{2}=1.25 \mathrm{~kg} \mathrm{~h}^{-1}$, $L_{3}=1.50 \mathrm{~kg} \mathrm{~h}^{-1}$

\section{Production Rate}

Condensate vinegar started to flow after about $18 \mathrm{~min}$ from the start of feeding or charging the pyrolyzer. A consistent trend was also observed in terms of the rate of production of vinegar. Molded fuels such as the briquettes have a significantly faster rate of producing vinegar as compared to the raw fuels, refer to Table 3 and Figure 6 . Larger briquettes produced $2.388 \mathrm{~L} \mathrm{~h}^{-1}$, at a faster rate than the raw 
fuel, which had a rate of $1.544 \mathrm{~L} \mathrm{~h}^{-1}$ only. It followed, too, that the rate of production varied with the loading rate. The main reason why briquettes could yield more and at a faster rate is that devolatilization is spontaneous when in solid and compact form without resorting so much to oxidation processes. Devolatilization occurs internally, starting from the inner core of the solid mass. Gases are consequently drawn out to the surface of the fuel where they react with oxygen in the air to complete the oxidation process. However, if the air is restricted in the chamber, massive gasification becomes predominant.

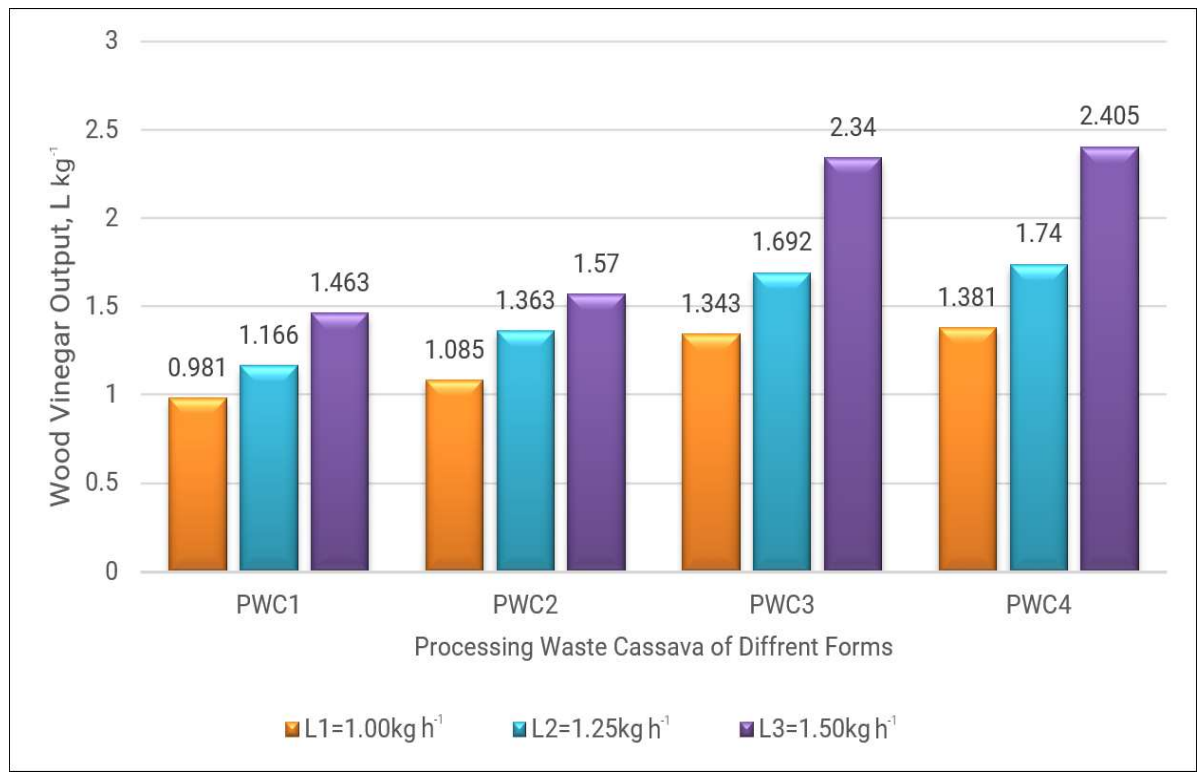

Figure 5. Wood vinegar output $\left(\mathrm{L} \mathrm{kg}^{-1}\right)$ extracted at different forms of processing wastes from cassava and loading rate $\left(\mathrm{kg} \mathrm{h}^{-1}\right)$

Table 3. Means of wood vinegar extraction rate $\left(\mathrm{Lh}^{-1}\right)$ from different processing waste forms from cassava and at different loading rates

\begin{tabular}{|c|c|c|c|c|}
\hline \multirow{2}{*}{ Processing Waste Form } & \multicolumn{3}{|c|}{ Loading Rate $\left(\mathrm{kg} \mathrm{h}^{-1}\right)$} & \multirow{2}{*}{$\begin{array}{l}\operatorname{Mean}^{* \star} \\
\left(L h^{-1}\right)\end{array}$} \\
\hline & $L_{1}$ & $\mathrm{~L}_{2}$ & $\mathrm{~L}_{3}$ & \\
\hline PWC1 & 0.981 & 1.458 & 2.194 & $1.544^{a}$ \\
\hline PWC2 & 1.085 & 1.704 & 2.355 & $1.715^{\mathrm{a}}$ \\
\hline PWC3 & 1.343 & 2.115 & 3.510 & $2.323^{b}$ \\
\hline PWC4 & 1.381 & 2.175 & 3.608 & $2.388^{b}$ \\
\hline Mean $^{\star \star}$ & $1.197^{\mathrm{a}}$ & $1.863^{\mathrm{b}}$ & $2.917^{c}$ & 1.992 \\
\hline
\end{tabular}


Rootcrops processing waste management

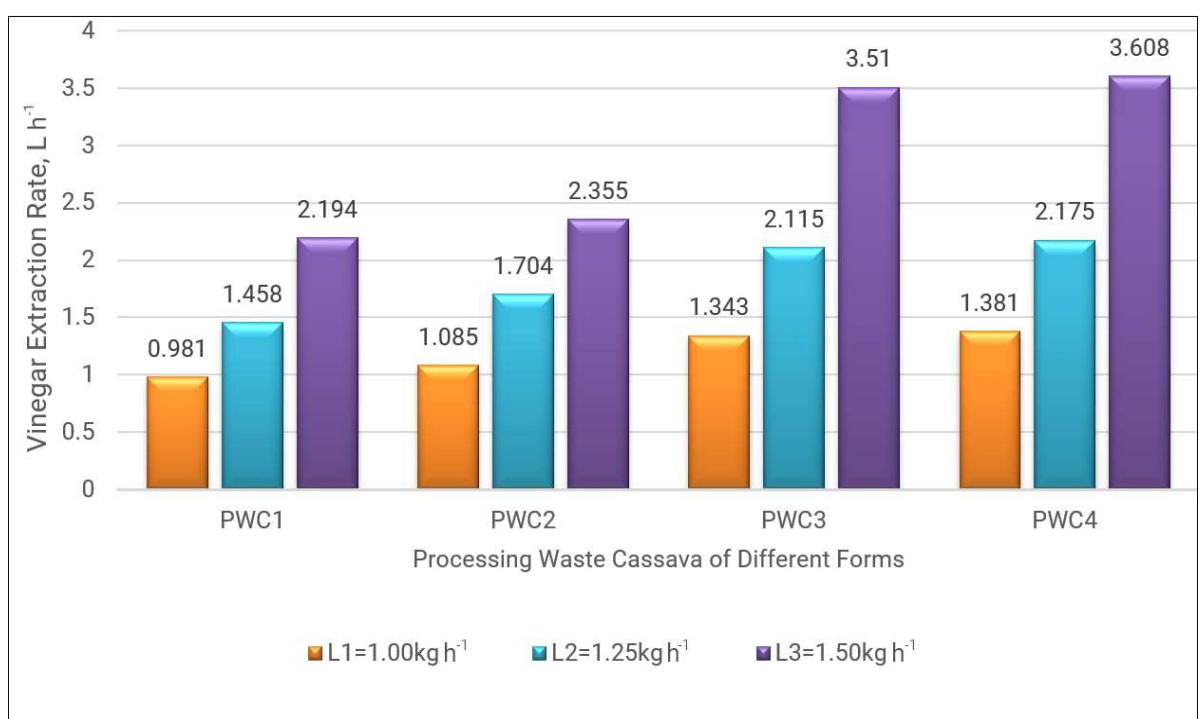

Figure 6. Wood vinegar extraction rate $\left(\mathrm{L} \mathrm{h}^{-1}\right)$ at different forms of processing waste from cassava and loading rate $\left(\mathrm{kg} \mathrm{h}^{-1}\right)$

\section{Flue Gas Temperature}

This observation above is further bolstered with the recorded prevailing flue gas temperature in the pyrolyzer, which is statistically constant with the unchanging amount of air supply into the chamber. As shown in Figure 7, temperatures were higher for fuels such as PWC2 and PWC1 or the raw and loose forms which ranged from 200.80 to $254.13^{\circ} \mathrm{C}$, respectively. Flue gas temperatures produced by both briquettes ranged from 118.43 to $150.97^{\circ} \mathrm{C}$, based on the maximum loading rate. These were the inlet temperatures at the condenser unit. The exit flue gas temperature did not vary significantly with fuel type but was highest for raw fuels at $45.57^{\circ} \mathrm{C}$ and lowest for the larger briquettes at $39.70^{\circ} \mathrm{C}$. This is in accordance with the explanation that fuels, which underwent more of the combustion reactions rather than gasification reaction processes, had produced less condensable gases and had created higher reaction gas temperatures. These were evident in the raw forms of fuels. The reverse is true for the briquette form of fuels, which produced more condensable gases and resulted in lower reaction gas temperatures.

\section{Heat Exchanger Efficiency}

The smoke tank, which served as the condenser unit, technically functions as a heat exchanger unit. The hot flue gas entering the tank transfered thermal energy by conduction and convection modes to the water, the coolant, or heat-absorbing medium without mixing directly. The parameter of "Logarithmic Mean Temperature Difference" (LMTD) is a mathematically simplified measure of the temperature gradient between two fluids in a heat exchanger. This is essential in determining the efficiency performance of the heat exchanger unit and in the calculation of energy 
transferred. For this prototype developed at PhilRootcrops, the condenser unit has achieved a lower value of LMTD at $45.67^{\circ} \mathrm{C}$. Higher values than this would mean a more efficient heat transfer and more gases would have been condensed. As shown in Figure 8, it remained insignificantly variable with the different fuel forms and loading rates, proving a desirable performance to warrant its function. Further, the mean temperature rise in the water was only $9.37^{\circ} \mathrm{C}$, and the mean temperature drop in the flue gas was $131.74^{\circ} \mathrm{C}$. The unit hardware design could be further improved by enhancing the conducting material and increasing the total contact area. Any modifications would be deemed successful if the resulting LMTD value was increased.

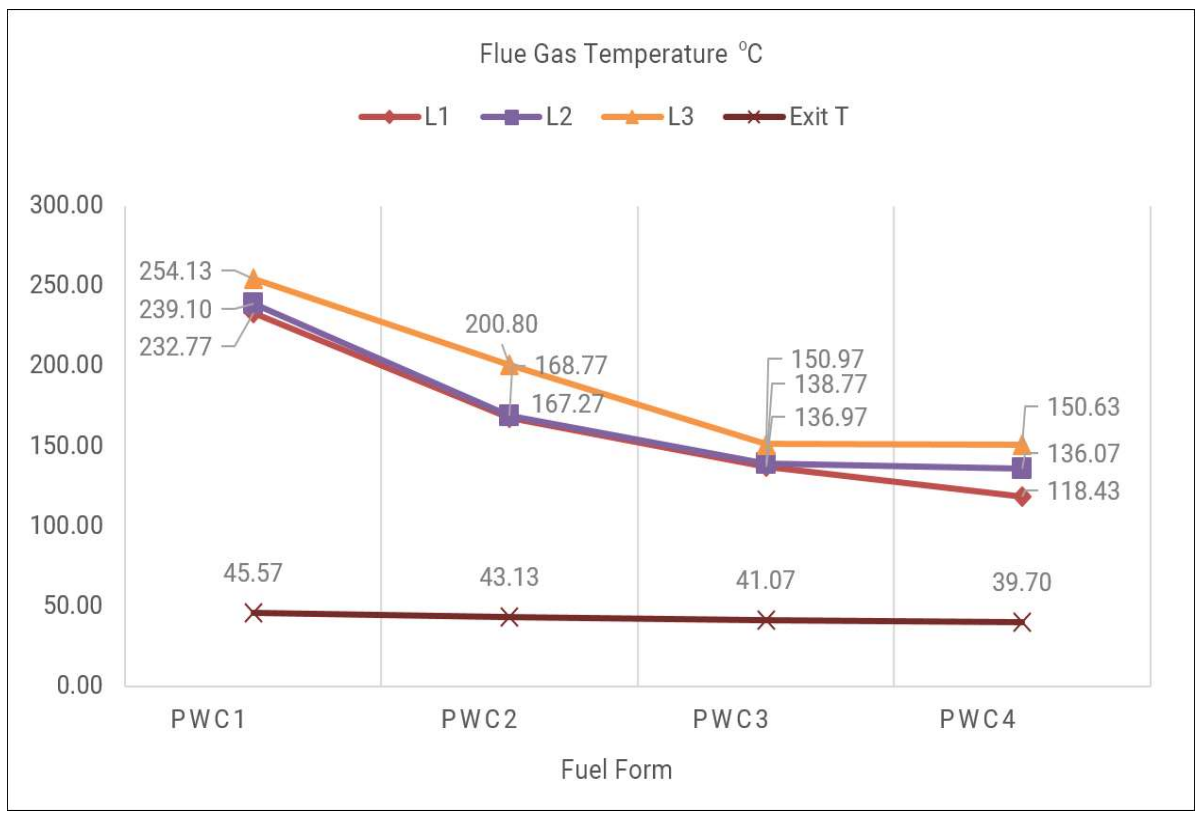

Figure 7. Flue gas temperatures entering and leaving the smoke tank/condenser unit

In summary, the concept of gasification plays the most important role in the optimum production of wood vinegar. Reactions spontaneously occurring in the pyrolysis chamber are both exothermic and endothermic processes, depending on the availability of the oxidizing agent, which is oxygen in the air. If the air supply is balanced, the result will be an autothermic condition. However, for more condensable gases to be produced as desirable output products, endothermic reactions should be favored more. These include water-gas, hydrogen gas dissociation, and other chemical reactions that require heat input in order to generate more condensable gases. Air is still necessary but of limited volume for the combustion exothermic reaction, the primary provider of heat. As earlier discussed, smaller bed porosity and smaller surface reaction area of the fuel particles contributed to a higher vinegar yield by restricting air supply and airflow within the fuel bed. This full, packed bed condition was also attained at higher loading rates. Lastly, for better vinegar yield, the heat exchanger design condition must demonstrate a higher LMTD value for better efficiency in enhancing phase 


\section{Rootcrops processing waste management}

change of flue gases. The current set-up used in this study has a lower LMTD value, which can contribute to a lower vinegar yield. The heat exchanger unit's design can still be improved by using good thermal conducting materials, reconfiguration, and increasing conductor interface area.

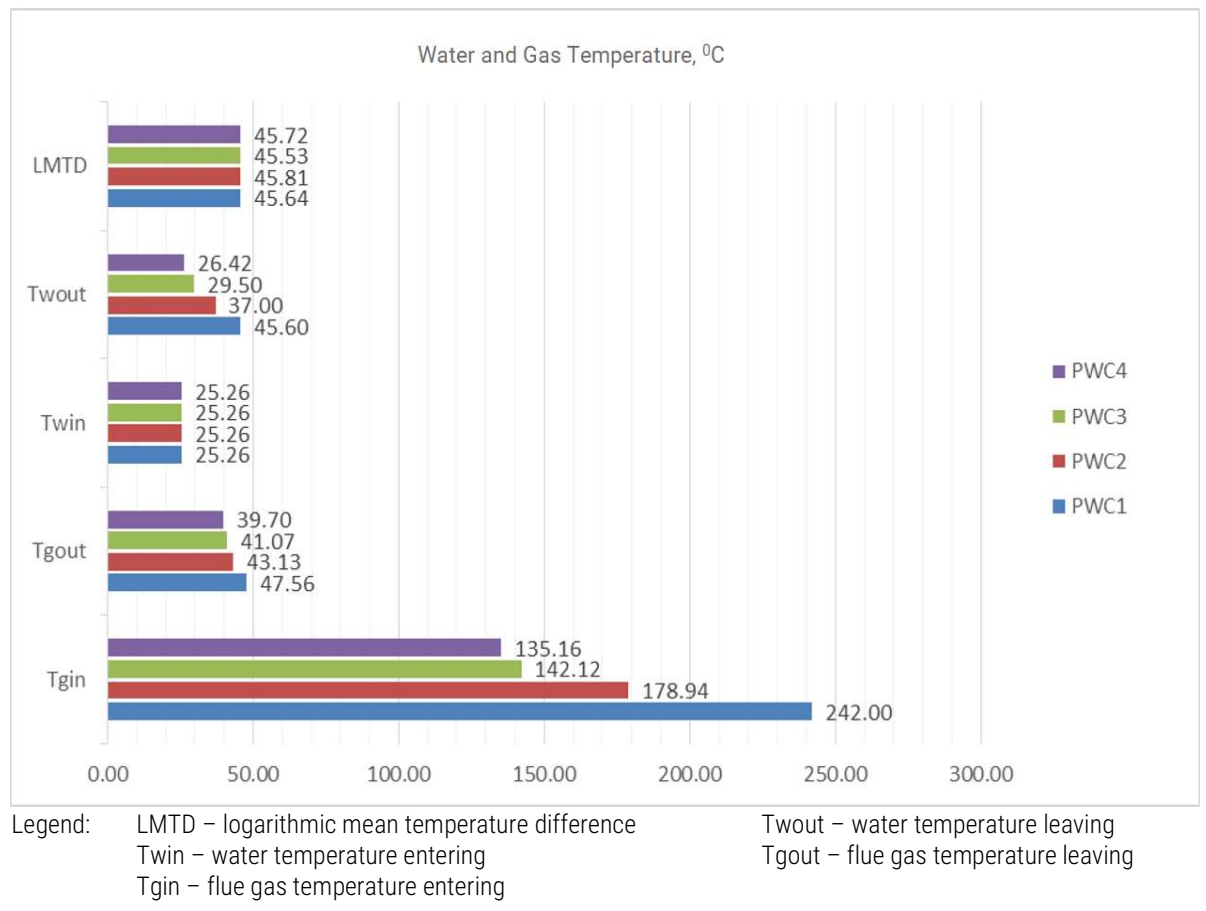

Figure 8. Mean water and gas temperatures $\left({ }^{\circ} \mathrm{C}\right)$ at the different ports of the condenser/smoke tank

\section{CONCLUSION AND RECOMMENDATION}

Processing wastes from cassava transformed into briquette form has been found to be significantly feasible by converting into wood vinegar. Specifically, the mean vinegar yield from briquette fuel (PWC4) was highest at $1.842 \mathrm{~L} \mathrm{~kg}^{-1}$ and lowest at $1.203 \mathrm{~L} \mathrm{~kg}^{-1}$ from shredded form (PWC3). The production rate was also fastest at 2.388 $\mathrm{L} \mathrm{h}^{-1}$ from the briquette form (PWC4) and lowest at 1.544L $\mathrm{h}^{-1}$ from the raw form (PWC1). In all fuel forms, the higher loading rate also produced higher vinegar yield. The following factors and their effect on vinegar yield are summarized below:

a) Fuel form: a molded form of fuel, as in briquettes, generates higher amounts of vinegar and in a faster way than loose unsegregated fuels.

b) Bed porosity: the smaller pore spaces in the bed favor more vinegar yield by restricting air supply.

c) Surface reaction area: the smaller projected surface area of the fuel particles provides fewer combustion reactions and thus more condensable gases are produced. 
d) Flue gas temperature: the allowable temperature in the pyrolysis chamber must be lower to produce more condensable gases.

e) Heat exchanger LMTD: the greater the value, the more efficient it is in condensing gases.

For further studies and follow-up research activities, the following areas of concern are recommended:

a) Improvement-modification of the wood vinegar generator set-up through scaling up and enhancing the heat exchanger unit.

b) Extensive field investigation and validation on the efficacy of applying wood vinegar derived from cassava wastes.

c) As an initial phase, the technology requires verification and pilot testing on a commercial scale.

d) Economic study is required to establish the cost of vinegar production and ROI.

\section{REFERENCES}

Appropriate Technology Association (ATA). Manual for 200-liter charcoal kilns. Nakhorn Ratchasima, Thailand

Brooker DB, Bakker-Arkema FW \& Hall CW. 1974. Drying cereal grains. The AVI Publishing Co., Inc. West Point, Connecticut

Food and Fertilizer Technology Center. 1998-2017. All rights reserved. Wood Vinegar. http://www.fftc.agnet.org

Henderson SM and Perry RL. 1976. Agricultural process engineering (3rd edn). The AVI Publishing Co., Inc. West Point, Connecticut

Leong S. 2011. The use of wood vinegar in reducing the dependence on agrochemicals. http://www.agrowingculture.org

Neale MA and Messer HJM. 1976. Resistance of root and bulb vegetables to airflow. Journal of Agricultural Research 21(3):221-231

Sadakichi, Kishimoto \& Hirowaka. 2017. Wood vinegar and biochar in agriculture. How to improve crop quality while reducing dependence on agricultural chemicals. http://webcache.googleusercontent.com

Tan DS and Orias RR. 2008. Primary cassava processing in the Philippines. Visayas State University, Baybay City, Leyte

Tardo CM. 2016. Design, construction, and evaluation of wood vinegar (Pyroligneous Acid) generator (BS thesis). Visayas State University, Baybay City, Leyte

Wood Vinegar Australia. 2017. Introduction to wood vinegar for Australian agriculture. http://www.woodvinegar.com.au/wood_vinegar_introduction_to_agriculture/ 